\title{
Grazing effects of blue mussel Mytilus edulis on the pelagic food web under different turbulence conditions
}

\author{
Marie Maar ${ }^{1,2, *}$, Torkel Gissel Nielsen ${ }^{1}$, Karsten Bolding ${ }^{2}$, Hans Burchard ${ }^{2,3}$, \\ André W. Visser ${ }^{4}$ \\ ${ }^{1}$ The National Environmental Research Institute, Department of Marine Ecology, Frederiksborgvej 399, PO Box 358, \\ 4000 Roskilde, Denmark \\ ${ }^{2}$ Bolding \& Burchard Hydrodynamics, Strandgyden 25, 5466 Asperup, Denmark \\ ${ }^{3}$ Baltic Sea Research Institute Warnemünde, Department for Physical Oceanography and Instrumentation, Seestraße 15, \\ 18119 Rostock-Warnemünde, Germany \\ ${ }^{4}$ Danish Institute for Fisheries Research, Department of Marine Ecology and Aquaculture, Kavalergaarden 6,
} 2920 Charlottenlund, Denmark

\begin{abstract}
Benthic filter feeders have the potential to control phytoplankton biomass and size composition in shallow estuaries and fjords, while the in situ impact on the zooplankton community is so far unknown. In a companion study, the blue mussel Mytilus edulis was shown to graze on both micro- and mesozooplankton causing depletion above the mussel bed (Nielsen \& Maar, Mar Ecol Prog Ser 339:185-198). However, the vertical zooplankton distribution varied between sampling days, and we thus examined the influence of turbulence on the escape capability of different zooplankton organisms. Two sampling days were selected for further analysis representing relatively low $\left(\varepsilon \approx 10^{-7} \mathrm{~m}^{2} \mathrm{~s}^{-3}\right)$ and high $\left(\varepsilon \approx 10^{-6} \mathrm{~m}^{2} \mathrm{~s}^{-3}\right)$ near-bed turbulence (estimated by a physical water column model, General Ocean Turbulence Model, GOTM). The grazing impact on the zooplankton was estimated by a random walk model taking zooplankton motility and escape behaviour into account as well as turbulence conditions. Protozooplankton and bivalve larvae were always captured efficiently by mussels irrespective of turbulence conditions, while the grazing impact on nauplii and copepodites was greatly reduced due to increased escape success in low turbulence conditions. Thus, the zooplankton community will be more diverse during low turbulence conditions and will compete with mussels for phytoplankton food. Seasonal importance of the different components of the pelagic food web for mussel consumption was evaluated by comparing the model results with plankton data from the studied fjord system. The analysis stresses the need, when evaluating the ecological role of mussels, to also consider the heterotrophic components of the food web.
\end{abstract}

KEY WORDS: Mytilus edulis $\cdot$ Filtration $\cdot$ Turbulence $\cdot$ Zooplankton $\cdot$ Escape responses

\section{INTRODUCTION}

It is well known that mussels are important grazers on phytoplankton, and a strong depletion of chlorophyll is often observed above mussel beds (Frechette et al. 1989, Dolmer 2000a). In addition, grazing experiments and analysis of stomach contents from field sam- ples have shown that mussels also ingest bacteria (Kreeger \& Newell 1996), protozooplankton (Kreeger \& Newell 1996), copepodites and nauplii (Lehane \& Davenport 2002, Green et al. 2003) and meroplankton (Cowden et al. 1984, Lehane \& Davenport 2002). However, the effects of mussel filtration on in situ vertical distributions and composition of the heterotrophic 
components of the pelagic food web have not been investigated. Some zooplankters are able to avoid predation by mussels because they can detect and escape from feeding currents (Singarajah 1975, Green et al. 2003). The escape success, however, depends on several factors. First, the fluid deformation rate generated by the predator must be detected in time to react and flee (Kiørboe \& Visser 1999). Second, the escape jump speed must exceed the suction flow speed of the mussels, and third, the jump must be away from the mussel bed (Green et al. 2003). The sensitivity to fluid deformation rate and the jump speed varies among zooplankton species, sizes and copepod stages (Viitasalo et al. 1998, Titelman \& Kiørboe 2003). In general, larger zooplankters are more likely to escape predation than smaller ones (Kiørboe \& Visser 1999), a fact which can be important in shaping the structure of the zooplankton community in shallow coastal waters. Another important factor is the turbulence level near the mussel bed, as this may affect the escape success of zooplankton. The 'background noise' due to turbulence interferes with the perception of the predator signal and, hence, enhances predation risk (Kiørboe et al. 1999). Strong turbulent vertical mixing may also prevent the zooplankton from escaping by transporting them back towards the mussel bed.

In the present study, we specifically examined the hypothesis that during high near-bed turbulence conditions, zooplankton will not be able to avoid predation by mussels. During periods with low turbulence, only zooplankton with poor escape capabilities are ingested, and the surviving zooplankton will compete with mussels for phytoplankton prey. Grazing impact on zooplankton organisms was estimated by a random walk model under different turbulence conditions estimated by a physical water column model.

\section{MATERIALS AND METHODS}

Sampling. Sampling took place in the shallow Limfjord, Denmark, with a total area of $1575 \mathrm{~km}^{2}$. The Limfjord is connected with the North Sea (32 to $34 \mathrm{psu}$ ) at its western entrance and with the Kattegat (19 to $25 \mathrm{psu}$ ) at its eastern entrance. Stratification during summer is determined both by salinity advection and solar heating during the daytime combined with surface cooling at night. The tidal amplitude is low (0.1 to $0.2 \mathrm{~m}$ ) and vertical mixing is mainly wind driven, indirectly through wave motion (Wiles et al. 2006). The Limfjord is stratified 45 to $70 \%$ of the time during summer and average annual wind velocity is $7.4 \mathrm{~m} \mathrm{~s}^{-1}$; wind mixing energy increases by a factor of 2 from summer to winter (Rasmussen 1997, Christiansen et al. 2006). The currents in the Limfjord arise from the main elevation gradient between the North Sea and the Kattegat and are driven by horizontal density gradients, regional wind field and local winds (Herman 2006).

Two study sites, in the centre of a sand bed and a mussel bed at Løgstør Bredning (56 $\left.56^{\prime} \mathrm{N}, 9^{\circ} 09^{\prime} \mathrm{E}\right)$, were visited from 26 May to 5 June 2003. Two days, 28 May and 1 June, were selected for further analysis in the present study because they represent the most pronounced differences in zooplankton vertical distributions, with no missing values near the bed (Table 5 in Nielsen \& Maar 2007, this volume) and in flow velocities (see 'Results'). Water column depths above the sandy site and the mussel site were approximately 5.5 and $6.0 \mathrm{~m}$, respectively, and the distance between them was $950 \mathrm{~m}$.

Vertical profiles of salinity and temperature were measured by a CTD (GMI AROP2000) immediately before biological sampling aboard RV 'Genetica' II (University of Aarhus). Vertical profiles of flow velocity were measured every $13 \mathrm{~min}$ by two $1200 \mathrm{kHz}$ RDI $\mathrm{ADCPs}_{\text {up }}$ (acoustic doppler current profiler configured to 'look upward' through the water column above the beds). The ADCPs measured water currents in $0.30 \mathrm{~m}$ bins and covered the water column from $1.66 \mathrm{~m}$ above the sand bed up to the surface and from 0.56 or $0.85 \mathrm{~m}$ above the mussel bed up to the surface. To achieve a higher vertical resolution of flow velocities towards the mussel bed, another $1200 \mathrm{kHz}$ RDI ADCP was configured to 'look downward' through the water column and covered 0.21 to $1.76 \mathrm{~m}$ above bottom in $0.05 \mathrm{~m}$ bins. The 2 ADCPs at the mussel site were situated $40 \mathrm{~m}$ apart. It was not possible to determine turbulent parameters with the ADCPs using the variance method due to the low energy levels during the study period (Wiles et al. 2006). Wind speeds and directions were obtained from the permanent meteorological station located on the island of Livø close to the sampling sites.

Biological sampling for estimation of chlorophyll a (chl a) concentrations and zooplankton abundances was conducted by a vertical high resolution sampler (HRS) taking 8 samples simultaneously from 0.14 to $1.47 \mathrm{~m}$ above the bottom at $0.19 \mathrm{~m}$ intervals (further details in Nielsen \& Maar 2007, this volume). Total sample volume was 1.51 at each depth, whereby 0.15 , 0.1 and 0.61 were used for estimation of chl a (3 replicates), abundance of protozooplankton and zooplankton $>45 \mu \mathrm{m}$, respectively, and the coefficient of variation of chl a was $<13 \%$. Maximum specific growth rates of protozooplankton were calculated from the average volume according to Hansen et al. (1997) assuming a growth yield of $26 \%$ (Straile 1997).

Modelling. An individual-based model was applied to simulate the observed plankton distributions and 
potential grazing impact of mussels on phytoplankton and zooplankton. The model was formulated to include both the physical and behavioural components of the plankton's motion. Realistic turbulence levels were first simulated by a physical water column model (see next subsection) and depth-dependent turbulent diffusivity was implemented in the individual-based model as a random walk. The domain for the random walk model covered the lower $1.5 \mathrm{~m}$ of the water column, roughly corresponding to sampling depth below the pycnocline (see Fig. 1). During the stratified period, the renewal of chl $a$ and zooplankton below the pycnocline is dependent on diffusion across the pycnocline, settling, active vertical migration, local production and advection. We assume here (1) that particles removed by mussel filtration are replaced by the above processes, keeping their abundance constant in the model and (2) that the thickness of the concentration boundary layer equals the thickness of the momentum boundary layer. Concentration fields of different plankton are therefore in steady state between turbulent mixing and removal by mussel filtration and can be solved quasi one-dimensionally (O'Riordan et al. 1995).

Turbulence modelling. To investigate the influence of turbulence on the escape success of zooplankton, turbulence was modelled on 28 May and 1 June, as these dates were assumed to represent relatively high and low near-bed turbulence conditions, respectively, based on the measured flow velocities (see Fig. 2). The applied one-dimensional water column model was the General Ocean Turbulence Model (GOTM: www.gotm.net) (Umlauf et al. 2005). Simulated temperature and salinity profiles were constructed by defining a surface and a bottom layer according to the observed vertical profiles of temperature and salinity (Table 1, see also Fig. 3). The simulated profiles were relaxed to the observed values on a time scale of 1 to $2 \mathrm{~h}$ to assure that the simulated profiles did not diverge from observations, which can be influenced by horizontal advection. The model was forced by a constant wind stress and a constant surface pressure gradient. The average $( \pm \mathrm{SD}) 10 \mathrm{~m}$ wind velocity $W$ was $2.9 \pm 0.3$ and $2.7 \pm$ $0.2 \mathrm{~m} \mathrm{~s}^{-1}$ and the wind direction was south-westerly and south-easterly on 28 May and 1 June, respectively, measured from $1 \mathrm{~h}$ before until the end of sampling. The wind stress $\left(\mathrm{N} \mathrm{m}^{-2}\right)$ model components in the E-W $\left(\tau_{\mathrm{x}}\right)$ and $\mathrm{N}-\mathrm{S}\left(\tau_{\mathrm{y}}\right)$ direction were estimated from:

$$
\begin{aligned}
& \tau_{\mathrm{x}}=C_{\mathrm{d}} \times \sigma \times W^{2} \times \cos (270-\text { deg. }) \\
& \tau_{\mathrm{y}}=C_{\mathrm{d}} \times \sigma \times W^{2} \times \cos (270-\text { deg. })
\end{aligned}
$$

where the surface drag coefficient $C_{\mathrm{d}}=2.5 \times 10^{-3}$ and air density $\sigma=1.25 \mathrm{~kg} \mathrm{~m}^{-3}$ and deg. is the wind direction in degrees. The surface pressure gradient was adjusted against observed data for each sampling occasion and the simulated flow velocities were relaxed to the observations by a time scale of 0.5 to $4 \mathrm{~h}$. The boundary conditions for the horizontal velocity components are constructed by assuming that the entire near-bed grid box is located inside a logarithmic boundary layer, which results in a quadratic friction law. The presence of a mussel bed is physically expressed by means of an increased bed roughness length $(0.001 \mathrm{~m}$ for sand and $0.01 \mathrm{~m}$ for mussel bed). Bed fluxes for temperature and salinity are set to zero.

The turbulent kinetic energy $(k)$ per unit mass and the dissipation rate of $k$ into heat per unit mass $(\varepsilon)$ are computed prognostically from parameterised transport equations, corresponding to the 2 equation $k-\varepsilon$ turbu-

Table 1. Input variables for simulations of physiochemical properties of water column in the General Ocean Turbulence Model

\begin{tabular}{|c|c|c|c|c|}
\hline \multirow[t]{2}{*}{ Parameters } & \multicolumn{2}{|c|}{$\longrightarrow 28$ May $\longrightarrow$} & \multicolumn{2}{|c|}{$\longrightarrow$ June $\longrightarrow$} \\
\hline & Sand bed & Mussel bed & Sand bed & Mussel bed \\
\hline Water column depth (m) & 5.50 & 6.00 & 5.50 & 6.00 \\
\hline End of surface layer (m) & 3.90 & 2.60 & 2.00 & 1.00 \\
\hline Salinity of surface layer & 22.42 & 22.45 & 22.92 & 22.59 \\
\hline Start of bottom layer (m) & 4.00 & 4.60 & 5.50 & 5.10 \\
\hline Salinity of bottom layer & 22.47 & 22.76 & 23.08 & 22.96 \\
\hline Lower limit of surface layer (m) & 1.00 & 2.00 & 1.50 & 0.50 \\
\hline Temperature of surface layer $\left({ }^{\circ} \mathrm{C}\right)$ & 14.27 & 13.91 & 15.97 & 15.52 \\
\hline Upper limit of bottom layer (m) & 3.0 & 4.40 & 5.00 & 2.00 \\
\hline Temperature of bottom layer $\left({ }^{\circ} \mathrm{C}\right)$ & 13.71 & 13.04 & 15.52 & 15.40 \\
\hline Relaxation for salinity/temperature (s) & 7200 & 7200 & 7200 & 3600 \\
\hline Surface pressure gradient $\mathrm{E}-\mathrm{W}$ & $0.36 \times 10^{-6}$ & $0.33 \times 10^{-6}$ & $0.24 \times 10^{-6}$ & $0.03 \times 10^{-6}$ \\
\hline $\mathrm{N}-\mathrm{S}$ & $0.22 \times 10^{-6}$ & $0.38 \times 10^{-6}$ & $0.08 \times 10^{-6}$ & $0.02 \times 10^{-6}$ \\
\hline Relaxation time for velocity profiles (s) & 14400 & 1800 & 14400 & 1800 \\
\hline \multirow[t]{2}{*}{ Wind stress, $\tau_{\mathrm{x}}, \tau_{\mathrm{y}}\left(\mathrm{N} \mathrm{m}^{-2}\right)$} & 0.024 & 0.024 & 0.018 & 0.018 \\
\hline & 0.011 & 0.011 & 0.014 & 0.014 \\
\hline
\end{tabular}
(GOTM) on 28 May and 1 June 2003 over sand and mussel Mytilus edulis bed 
lence closure model. The vertical eddy diffusivities of heat and tracers $K$ and the eddy viscosity for momentum were parameterised by means of the $k-\varepsilon$ model, where second turbulent moments were calculated from the algebraic closure suggested by Canuto et al. (2001). For details of the turbulence modelling approach, see Burchard \& Bolding (2001). The spin-up time to establish a stable turbulence profile was set at $1 \mathrm{~d}$ and the vertical discretisation between grid points was $0.1 \mathrm{~m}$. The background noise due to turbulence for zooplankton perception was estimated as the shear within a microscale turbulent eddy parameterised $\theta_{t}$ $\left(\mathrm{s}^{-1}\right)$ calculated from Karp-Boss et al. (1996):

$$
\theta_{t}=\left(\varepsilon v^{-1}\right)^{1 / 2}
$$

where $v$ is the kinematic viscosity of seawater $\left(\sim 10^{-6} \mathrm{~m}^{2} \mathrm{~s}^{1}\right)$.

Random walk model. Phytoplankton were assumed to be sinking with constant velocity, while zooplankton can have a directed swimming behaviour in response for example to light, temperature, food, predators or turbulence. This velocity $W\left(\mathrm{~m} \mathrm{~s}^{-1}\right)$ is negative for sinking/downward swimming and positive for upward swimming and was estimated by fitting the simulated profiles against the observed profiles above the sand bed (see 'Results'). Zooplankton swimming behaviour was also described as non-directional random zooplankton swimming i.e. 'biodiffusion' $D\left(\mathrm{~m}^{2} \mathrm{~s}^{-1}\right)$ constant over the water column given by (Berg 1983):

$$
D=\frac{u^{2} \times \gamma}{3}
$$

where $u\left(\mathrm{~m} \mathrm{~s}^{-1}\right)$ is typical swimming speed and $\gamma(\mathrm{s})$ is the average time between changes in random swimming directions (tumbles). We here use the 3D biodiffusion estimate because the used swimming speed is in 3D and not just its speed in the vertical direction. This gives us an estimate of the biodiffusivity, which we then use in our 1D model to calculate random vertical motion

The flow field associated with mussel filtration is composed of a narrow, intense exhalent flow and a broad, gentler inhalant flow. The exhalent flow can be modelled as a steady jet generated by a pump (Batchelor 2000, p 205), a model that conforms reasonably well to observations (Green et al. 2003). The exhalent flow velocity $\left(v_{\mathrm{ex}}\right)$ at a distance $z$ above the mussels can thereby be estimated as

$$
v_{\mathrm{ex}}=\frac{Q}{\pi r_{\mathrm{ex}}\left(r_{\mathrm{ex}}+z\right)}
$$

where $Q$ is the volume flux of the mussel filtration, and $r_{\text {ex }}$ is the radial dimension of the exhalent mouth. This model captures the essential features of the flow; that it is inversely proportional to distance from the exhalent mouth (Batchelor 2000), and that the flow remains finite and consistent with the volume flux at the exhalent mouth. Conversely, the inhalant flow is more akin to a siphon flow bounded by a horizontal plane. As such, the velocity associated with the inflow can be modelled as:

$$
V_{\text {in }}(z)=\frac{Q}{2 \pi\left(r_{\text {in }}+z\right)^{2}}
$$

where $r_{\text {in }}$ is the radial dimension of the inhalant mouth. Again, the essential features of this formulation are that the flow speed is such that the volume flux remains constant for any sized hemisphere centred on the inhalant mouth, and that the flow speed remains finite at the inhalant mouth $(z=0 \mathrm{~m})$. Maximum clearance was $Q=1.01 \mathrm{~h}^{-1}$ individual $^{-1}$ (Kiørboe \& Møhlenberg 1981) assuming $100 \%$ capture efficiency with linear temperature correction (Riisgaard \& Seerup 2003) for mussels with a median shell length of $2.3 \mathrm{~cm}$ at the study site. Maximum exhalent siphon area was $6.5 \times 10^{-5} \mathrm{~m}^{2}$ for an $8.1 \mathrm{~cm}$ Mytilus edulis (Newell et al. 2001). The $r_{\mathrm{ex}}=0.12 \mathrm{~cm}$ was found by scaling this siphon area to the present shell length using an exponent of 2 assuming that siphon area is proportional to clearance rate; $r_{\text {in }}=0.24 \mathrm{~cm}$ was found by assuming that the ratio of inhalent to exhalent radius was a factor of 2 (O'Riordan et al. 1995). As a result, the filtration velocity is 8 times higher for the exhalent than for the inhalant flow. Since the net flux is zero, this ratio (i.e. 1:8) is proportional to the relative surface area projected on a horizontal plane and gives the probability of encountering the exhalent versus inhalent flow. Organisms that encounter the exhalent jet are not immediately destined for consumption by the mussels. Of more immediate concern is the escape reaction induced by the inflow. Given the inhalent flow field, the deformation rate $\theta_{\mathrm{m}}\left(\mathrm{s}^{-1}\right)$ generated by filtration at distance $z$ above the mussel can be estimated as

$$
\theta_{\mathrm{m}}(z)=\frac{-Q}{\pi\left(r_{\mathrm{in}}+z\right)^{3}}
$$

In addition to sinking, biodiffusion and directional swimming, plankton move randomly in space and time due to turbulence expressed by the turbulent diffusivity $K$. The random walk model simulating the vertical distribution of particles was corrected for varying turbulent diffusivity with depth to prevent the non-physical accumulation of passive particles in low turbulence areas of the water column (Visser 1997). The change in the vertical position from $z_{n}$ to $z_{n+1}$ over a finite time step $\delta t(=10 \mathrm{~s})$ of each of the particles in the water column was estimated by

$z_{\mathrm{n}+1}=z_{\mathrm{n}}+\left[V_{\mathrm{m}}+w\right] \delta t+K^{\prime}\left(Z_{\mathrm{n}}\right) \delta t+R_{1}\left\{2 r^{-1}\left[K\left(z_{\mathrm{off}}\right)+D\right] \delta t\right\}^{1 / 2}$ 
The second term is the mussel filtration velocity $V_{\mathrm{m}}$ assigned to be exhalent ( $V_{\text {ex }}$, Eq. 5) or inhalant ( $V_{\text {in }}$ Eq. 6) by the ratio 1:8. The second term also contains the non-random directed sinking/swimming velocity $w$. The third term is a non-random advection from areas of low diffusivity to areas of high diffusivity, where $K^{\prime}$ denotes the gradient in diffusivity at depth $z_{\mathrm{n}}$ (Visser 1997). The fourth term is the turbulent diffusivity $K$ and biodiffusivity $D$ (Eq. 4), both multiplied by a random function $R_{1}$ that generates a uniform distribution between -1 and 1 and a constant $r=1 / 3$ (Visser 1997 ). Note that $K$ is computed at position offset $z_{\text {off }}$, set off by half the diffusivity gradient correction length (Visser 1997):

$$
z_{\text {off }}=z_{\mathrm{n}}+0.5 \times K^{\prime}\left(z_{\mathrm{n}}\right) \times \delta t
$$

The random walk model simulated the profiles and grazing impact on chl a, protozooplankton, Centropages hamatus copepodites and nauplii, and bivalve larvae with different motility and escape responses. At the critical detection depth $z_{\mathrm{cr}}$, the zooplankton performed an escape jump with maximum jump velocity $W_{\text {max }}\left(\mathrm{cm} \mathrm{s}^{-1}\right)$ in the direction upwards and away from the inhalent flow, which also has been observed in siphon flow experiments (Titelman \& Kiørboe 2003). However, $w_{\max }$ was multiplied by the random function $R_{0}$ generating a uniform distribution between 0 and 1 because not all individuals may be able to jump by $w_{\text {max }}$. We assume that all particles crossing the lower boundary are captured by mussels with $100 \%$ efficiency and are counted before they are transferred back to the water column at random depth. Above the sand bed, the lower boundary is reflective, with particles mirrored back onto the bottom. Particles crossing the upper boundary at both sites are transferred back to a random depth in the water column, but without being counted. The upper boundary is not reflective because there is a loss of particles moving higher up in the water column out of the model layer of $1.5 \mathrm{~m}$. The random walk model was developed and run in Matlab (Version 6.0.0.88).

Particles were initially homogenously distributed throughout the water column and 300 particles of each type were used to simulate different groups of plankton. The simulated vertical profiles were in quasisteady state after approximately $0.5 \mathrm{~h}$ (180 time steps) and simulation time was set to $1 \mathrm{~d}$ to achieve sufficiently high captures for statistical analysis. The average (3 replicates) simulated grazing impact $G\left(\mathrm{~d}^{-1}\right)$ of mussels on chl $a$ and different zooplankton groups $\mathrm{d}^{-1}$ could be estimated from the total encounters $E$ (particles $\left.\mathrm{m}^{-2} \mathrm{~d}^{1}\right)$, divided by their concentration $(C=200$ particles $\mathrm{m}^{-3}$ ) and water column depth, $H(H=1.5 \mathrm{~m})$ and multiplied by the average coverage (cov) of $27 \%$ of blue mussels on the sea bed (Herman 2006):

$$
G=\frac{E \mathrm{cov}}{C H}
$$

Vertical profiles were plotted for every $0.08 \mathrm{~m}$ over the $1.5 \mathrm{~m}$ water column above the bottom and rescaled to the observed values at a depth of $1.28 \mathrm{~m}$, where a peak was observed on 1 June. The coefficient of variation (SD/mean) of 3 replicates was typically $<10 \%$. Seasonal contributions of the different plankton organisms to mussel diet were calculated from the monthly plankton biomass composition in the Limfjord (Limfjordsovervågningen 2002) multiplied by the respective simulated grazing impacts by mussels on 28 May and 1 June assumed to represent maximum and minimum values, respectively. Bacteria attached to particles were also assumed to be consumed by mussels on 28 May with an efficiency of 30\% (Møhlenberg \& Riisgaard 1978).

\section{RESULTS}

\section{Physiochemical properties}

The water column was stratified during the study period except on 31 May and 3 June, when it was mixed due to increased wind speed and wave motion (Fig. 1). In the near-bed mussel layer $(<1.76 \mathrm{~m})$, the measured mean flow velocities were below $0.07 \mathrm{~m} \mathrm{~s}^{-1}$ (Fig. 2) and the general direction was $\mathrm{N}$ to NW from the sand bed towards the mussel bed. On 28 May, flow velocity and near-bed shear were substantially higher than on the other days, leading to fairly mixed nearbed conditions. This suggests that turbulence in the near-bed region was strongest on 28 May. When the water column was stratified, the flow frequently exhibited a 2-layer structure with opposing flows in surface and near-bed layers (Wiles et al. 2006) shaping the vertical mean flow velocity profiles (Fig. 3). The physical water column model GOTM succeeded reasonably well in reproducing the observed vertical profiles of salinity, temperature and the mean flow velocity above the mussel bed on 28 May and 1 June (Fig. 3).

The simulated turbulent dissipation rate $(\varepsilon)$ was highest at the surface and bottom and decreased within the stratified layer (Fig. 4a). Further, $\varepsilon$ was 1 order of magnitude higher on 28 May $\left(\sim 10^{-6} \mathrm{~m}^{2} \mathrm{~s}^{-3}\right)$ than on 1 June $\left(\sim 10^{-7} \mathrm{~m}^{2} \mathrm{~s}^{-3}\right)$ near the mussel bed. $K$ decreased within the stratified layer and towards the surface and bottom due to a reduction in mixing length scales (Fig. 4b). Maximum $K$ below the pycnocline was 2.4 and $0.9 \times 10^{-4} \mathrm{~m}^{2} \mathrm{~s}^{-1}$ on 28 May and 1 June, respectively (Fig. 5). Different combinations of parabolic and linear functions were fitted against the GOTM-simulated $K$ in the lower $1.5 \mathrm{~m}$ of the water column and used to compute $K$ in the random walk model. 


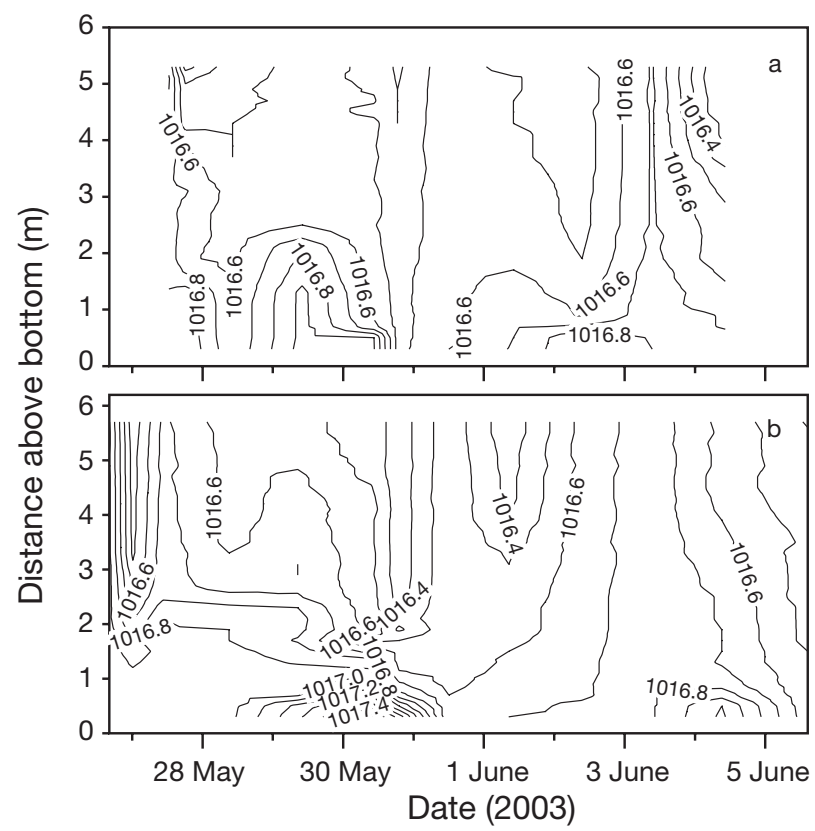

Fig. 1. Density $\left(\mathrm{kg} \mathrm{m}^{-3}\right)$ above (a) sand bed and (b) mussel Mytilus edulis bed during study period

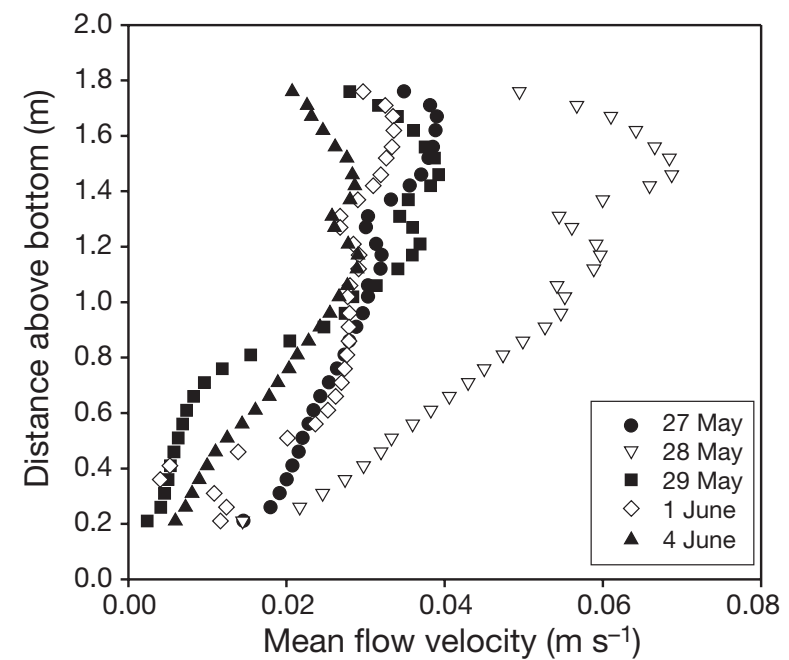

Fig. 2. Vertical profiles of mean flow velocity measured near mussel Mytilus edulis bed on the $5 \mathrm{~d}$ on which biological parameters were sampled in May and June 2003

\section{Chlorophyll a}

The observed profiles of chl a showed increasing concentrations towards the sand bed due to settling, while there was a statistically significant depletion above the mussel bed on both 28 May and 1 June, tested by ANCOVA with $\ln (\mathrm{z})$ as the covariate $\left(F_{12,1}\right.$, $\mathrm{p}<0.05)$ (Fig. 6). The average $( \pm \mathrm{SD}) \mathrm{chl}$ a concentrations were $4.6 \pm 1.4$ and $4.4 \pm 0.6 \mathrm{mg} \mathrm{m}^{-3}$ above the sand bed and $1.8 \pm 0.3$ and $2.5 \pm 0.4 \mathrm{mg} \mathrm{m}^{-3}$ above the mussel bed on 28 May and 1 June, respectively. The phytoplankton community was dominated by diatoms and primary production rates $(>2 \mu \mathrm{m}) 1 \mathrm{~m}$ above the mussel bed were 15 and $18 \mathrm{mg} \mathrm{C} \mathrm{m}^{-3} \mathrm{~d}^{-1}$ on 28 May and 1 June, respectively (Herman 2006). Using a C:chl a of 40, this gives a specific growth rate of $\sim 0.20 \mathrm{~d}^{-1}$ in the lower $1 \mathrm{~m}$ (Table 2).

Chl a sinking velocities were 0.4 and $0.1 \mathrm{~m} \mathrm{~d}^{-1}$ on 28 May and 1 June, respectively, obtained by fitting the simulated profiles against the observed profiles of chl a above the sand bed (Fig. 6). Chl a profiles above the mussel bed were simulated both with and without mussel filtration (control) using the same $w_{\text {sink }}$ as for the sand bed. This shows that the observed profiles were also influenced by mussel filtration, not only by the different hydrodynamics. Simulated grazing impact on chl a by mussels increased slightly with increasing sinking velocity and was 1 order of magnitude higher on 28 May (due to an increased downmixing of phytoplankton) than on 1 June (Fig. 7). Using the fitted $w_{\text {sink }}$ the average $( \pm$ SD) grazing impact on the phytoplankton community was $8.8 \pm 0.4$ and $0.39 \pm 0.1 \mathrm{~d}^{-1}$ on 28 May and 1 June, respectively, (Table 2).

\section{Zooplankton composition}

The dominant zooplankton groups in the Limfjord were athecate and thecate dinoflagellates (10 to $40 \mu \mathrm{m}$ in length), oligotrich ciliates and Myrionectra rubrum (10 to $40 \mu \mathrm{m})$, nauplii (100 to $300 \mu \mathrm{m}$ ) and copepodites (300 to $800 \mu \mathrm{m})$ of Centropages hamatus, polychaete trochophores (100 to $200 \mu \mathrm{m})$ and bivalve larvae (100 to $250 \mu \mathrm{m}$ ). There was a statistically significant difference in depth distributions (depth on ln-scale) of protozooplankton (dinoflagellates and ciliates) between the sand bed and the mussel bed on 28 May $\left(\right.$ ANCOVA, $\left.F_{1,28}=9.091, \mathrm{p}<0.05\right)$ and 1 June (ANCOVA, $F_{1,28}=4.837, \mathrm{p}<0.05$ ) indicating that mussels grazed them on both days (Fig. 8). Calculated maximum specific growth rates of protozooplankton varied from 0.37 to $0.82 \mathrm{~d}^{-1}$ (Table 2). Vertical distributions of nauplii, copepodites and bivalve larvae were statistically significantly different between the sand bed and the mussel bed on 28 May (ANCOVAs, $F_{1,12}=$ 5.169 - 25.946, p < 0.05), but not on 1 June (ANCOVAs, $\left.F_{1,12}=0.405-2.544, \mathrm{p}>0.05\right)$. Specific average $( \pm \mathrm{SD})$ growth rates estimated from egg production were 0.31 \pm 0.10 and $0.21 \pm 0.07 \mathrm{~d}^{-1}$ on 28 May and 1 June, respectively (Table 2 and T. G. Nielsen unpubl. data). For modelling, 5 types of plankton were considered: 2 groups of protozooplankton (dinoflagellates and ciliates), nauplii, copepodites and bivalve larvae. This classification was made as each group has quite dis- 

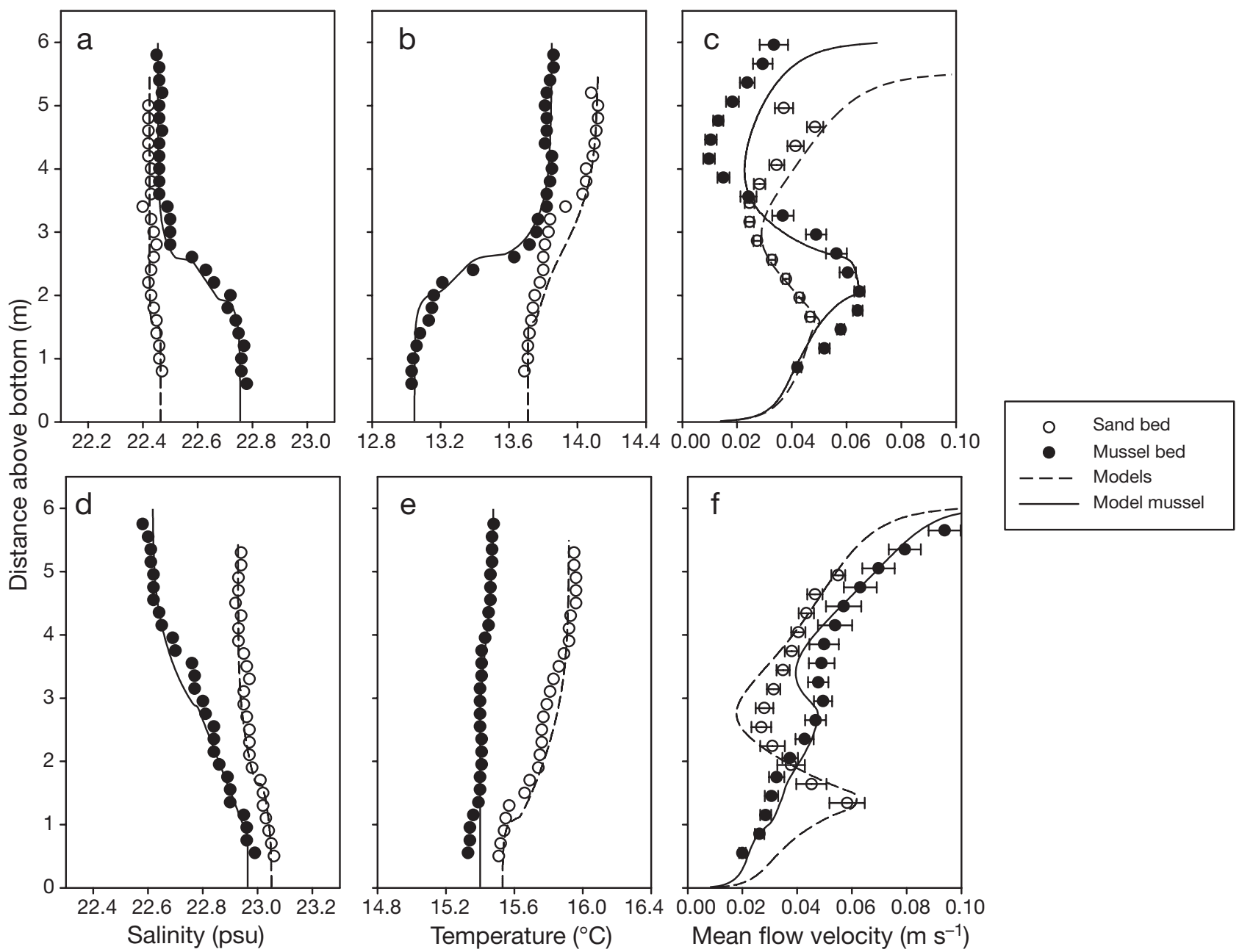

Fig. 3. Observed and simulated profiles of salinity, temperature and mean flow velocity $( \pm \mathrm{SE})$ above sand Mytilus edulis bed and the mussel bed on (a) to (c) 28 May and (d) to (f) 1 June
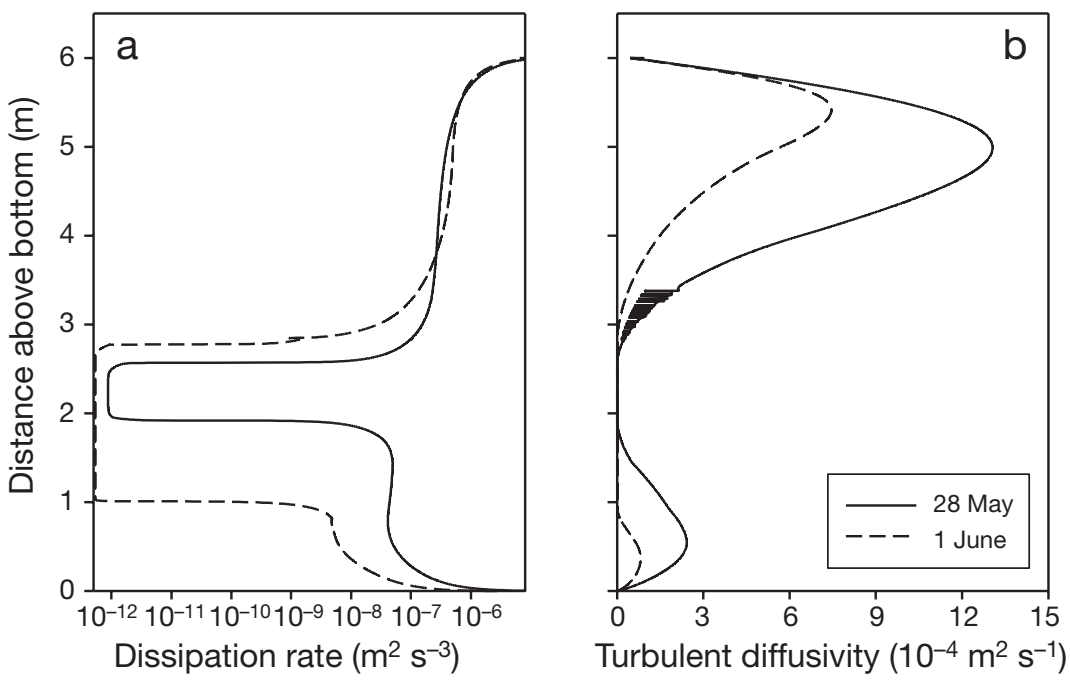

Fig. 4. Simulated (a) turbulent dissipation rate $\varepsilon$ on log scale, and (b) diffusivity $K$ above mussel Mytilus edulis bed on 28 May and 1 June tinct motility patterns, swimming abilities and escape behaviours. Polychaete trochophores were not considered, due to insufficient knowledge of their motility and escape behaviour.

\section{Critical detection depth}

Mussel filtration velocity increases nearer the mussel and the risk of being captured increases with lower zooplankton sensitivity and, hence, lower critical detection depth. For detection, the signal (mussel filtration, Eq. 7) must exceed the background noise (shear, Eq. 3). Hence, the zooplankton had the possibility to detect the mussels at $<4$ and $18 \times 10^{-4} \mathrm{~m}$ 

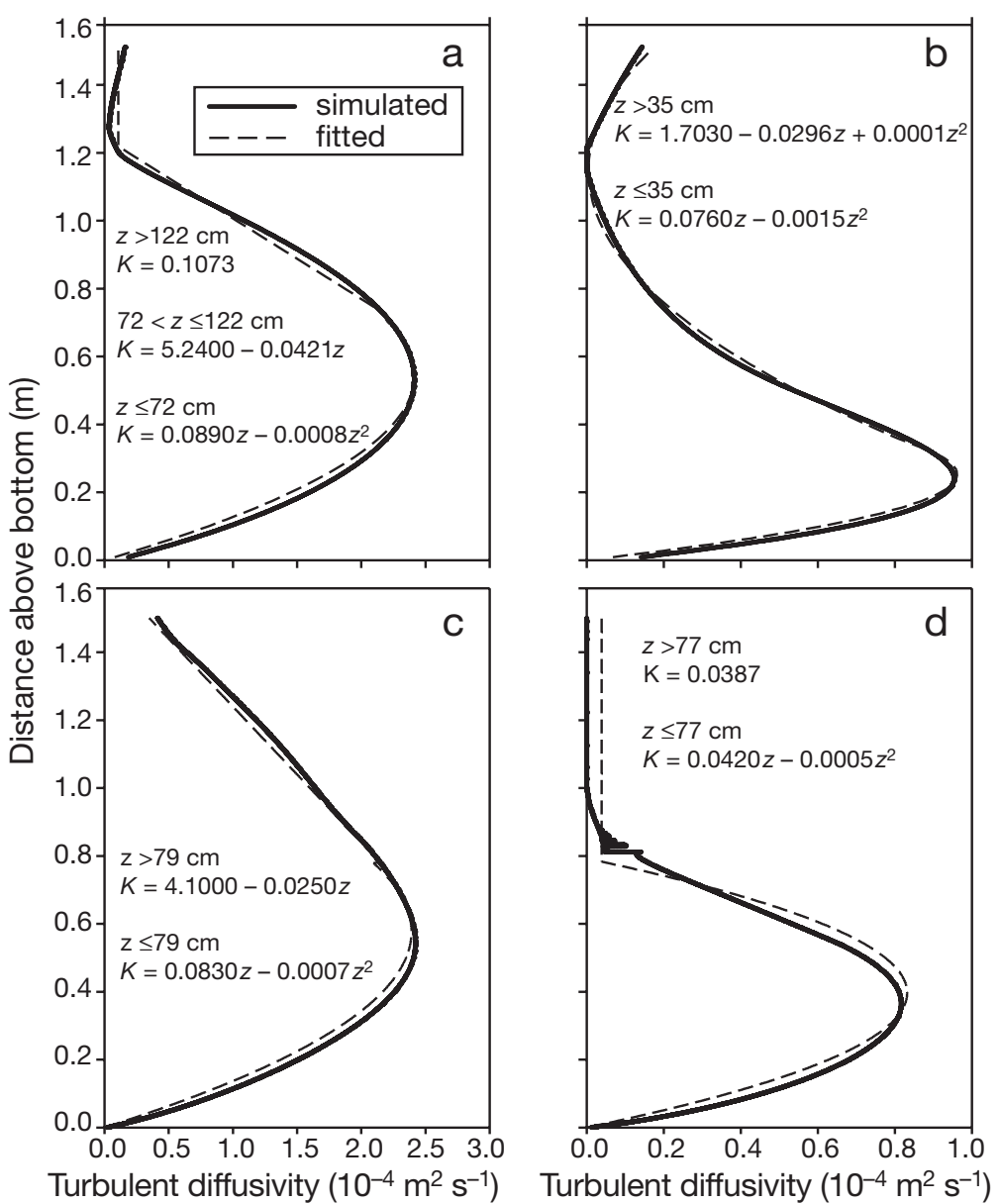

Fig. 5. Simulated turbulent diffusivity $(K)$ versus depth $(z)$ and fitted equations for $K$ used in random walk model above (a) sand bed on 28 May, (b) sand bed on 1 June, (c) mussel Mytilus edulis bed on 28 May and (d) mussel bed on 1 June

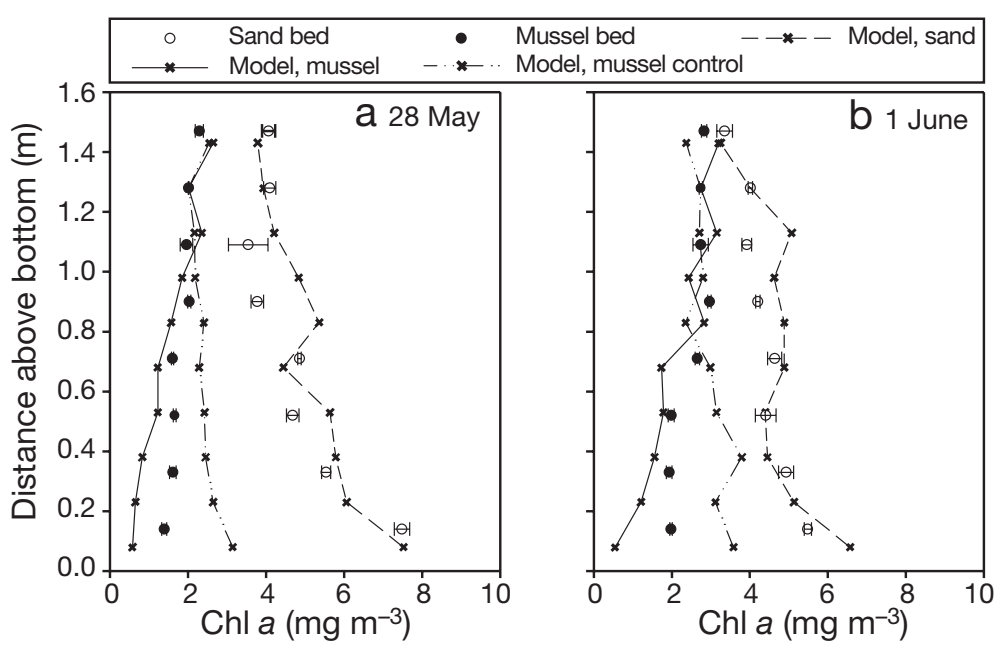

Fig. 6. Observed $( \pm \mathrm{SE})$ and simulated profiles of chlorophyll $a$ above sand and mussel Mytilus edulis beds on (a) 28 May, $w_{\text {sink }}=0.4 \mathrm{~m} \mathrm{~d}^{-1}$, and (b) 1 June, $w_{\text {sink }}=0.1 \mathrm{~m} \mathrm{~d}^{-1}$, where $w_{\text {sink }}=$ sinking velocity. Controls are simulations for mussel bed without mussel filtration. Coefficients of variation varied from 15 to $19 \%$ (simulated values) above the mussels at a deformation rate $\theta_{\mathrm{m}}$ of 4.6 and $1.4 \mathrm{~s}^{-1}$ on 28 May and 1 June, respectively (Fig. 9).

To show the effect of the critical detection depth $z_{\text {cr }}$ on escape success, the grazing impact was simulated for copepod nauplii with a biodiffusion $D$ of $0.013 \mathrm{~cm}^{2} \mathrm{~s}^{-1}$ (Tiselius \& Jonsson 1990) in calm water $(\varepsilon=$ 0 ) and in high and low turbulence conditions on 28 May and 1 June, respectively (Fig. 10). The grazing impact decreases considerably with increasing $z_{\mathrm{cr}}$ in calm water, while this effect diminishes with increasing turbulence due to the higher mixing of particles nearer the mussels. The grazing impact was several orders of magnitude higher under turbulent conditions compared to calm water at the same critical detection depth (Fig. 10). Hence, escape responses are only efficient under very low turbulence intensities.

Mussel size distribution affects filtration rate and deformation rate and potentially the grazing impact. This was tested for copepod nauplii ingested by mussels with shell lengths of 0.2 (min.) and $5.8 \mathrm{~cm}$ (max.) by allometric changes of volume flux $Q$ and $r_{\text {in }}$ in Eqs. (5), (6) and (7) and $z_{\mathrm{cr}}$ in the model. The siphon opening of the smallest mussels was accordingly $0.03 \times 0.06 \mathrm{~cm}$, corresponding to the size of larger zooplankton. There were no significant differences in grazing impacts between mussels with minimum, maximum and median shell lengths (ANOVA, $\left.F_{2,12,14}=1.041, \mathrm{p}>0.05\right)$. Thus, the positive effect of increasing $Q$ on grazing impact was counteracted by a higher $z_{\mathrm{cr}}$ that allowed nauplii to escape to a greater distance from the mussel beds.

\section{Vertical profiles and grazing impact on zooplankton}

\section{Protozooplankton}

Vertical profiles above the beds and grazing impact on dinoflagellates and ciliates were simulated by assuming $u=0.033 \mathrm{~cm}$ $\mathrm{s}^{-1}$ and $\gamma=11 \mathrm{~s}$ (Broglio et al. 2001) corresponding to a $D$ of $0.004 \mathrm{~cm}^{2} \mathrm{~s}^{-1}$ according to Eq. (4). However, dinoflagellates and ciliates were correlated to the chl a concentrations above the sand bed on 28 May and $W_{\text {down }}=1.2 \times 10^{-3} \mathrm{~cm} \mathrm{~s}^{-1}\left(=1 \mathrm{~m} \mathrm{~d}^{-1}\right)$ obtained by fitting the simulated profiles against 
Table 2. Specific growth rate $\left(\mathrm{d}^{-1}\right)$ and modelled grazing impact $G\left(\mathrm{~d}^{-1}\right)$ on phytoplankton and zooplankton

\begin{tabular}{|c|c|c|c|c|}
\hline \multirow[t]{2}{*}{ Group } & \multicolumn{2}{|c|}{-28 May } & \multirow{2}{*}{$\begin{array}{c}1 \text { June } \\
\text { Spec. growth } \\
\text { rate }\end{array}$} & \multirow[b]{2}{*}{$G$} \\
\hline & $\begin{array}{l}\text { Spec. growth } \\
\text { rate }\end{array}$ & G & & \\
\hline Phytoplankton & 0.20 & 8.8 & 0.18 & 0.39 \\
\hline Dinoflagellates & 0.47 & 8.2 & 0.37 & 0.36 \\
\hline Ciliates & 0.82 & 8.1 & 0.65 & 0.32 \\
\hline Copepod nauplii & 0.31 & 5.6 & 0.21 & 0.02 \\
\hline Copepodites & 0.31 & 1.9 & 0.21 & 0.01 \\
\hline Bivalve larvae & - & 8.2 & - & 0.16 \\
\hline
\end{tabular}

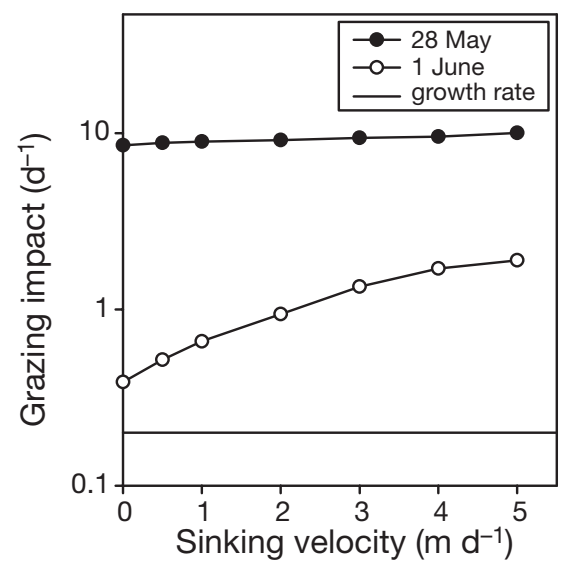

Fig. 7. Average simulated grazing impacts on chlorophyll $a$ on 28 May and 1 June versus different sinking velocities at a growth rate of $0.20 \mathrm{~d}^{-1}$. Coefficients of variation (SD/mean) were less than $5 \%$

observed profiles (Fig. 8). It was not necessary to add a directed swimming velocity on 1 June to obtain the observed profiles.

$W_{\max }$ was fitted to 0.4 and $0.6 \mathrm{~cm} \mathrm{~s}^{-1}$ for dinoflagellates and ciliates, respectively, by fitting the simulated profiles against the observed profiles in Fig. 8. The grazing impact (Eq. 10) decreased with increasing escape jump velocity (Fig. 11a), and $w=0 \mathrm{~cm} \mathrm{~s}^{-1}$ was $\sim 8.1 \mathrm{~d}^{-1}$ on 28 May and 0.32 to $0.36 \mathrm{~d}^{-1}$ on 1 June, respectively at (Table 2). The grazing impact increased by only $3 \%( \pm 0.1 \mathrm{SD})$ when adding $w_{\text {down }}=$ $1.2 \times 10^{-3} \mathrm{~cm} \mathrm{~s}^{-1}$ to the simulations on 28 May (pairwise $t$-test, $\mathrm{df}=6, \mathrm{p}<0.05)$. In calm water, the grazing impact was further reduced to $<0.04 \mathrm{~d}^{-1}$ at $z_{\mathrm{cr}}=$ $0.11 \mathrm{~cm}\left(\theta_{\mathrm{m}}=2 \mathrm{~s}^{-1}\right)$.

\section{Nauplii and copepodites of Centropages hamatus}

The vertical profiles above the beds and grazing impact by mussels were simulated by using $u=0.1 \mathrm{~cm}$ $\mathrm{s}^{-1}$ and $\gamma=4 \mathrm{~s}$ on both days (Tiselius \& Jonsson 1990) corresponding to $D=0.013 \mathrm{~cm}^{2} \mathrm{~s}^{-1}$ (Eq. 4). On 28 May, nauplii and copepodites were probably attracted to the chl a maximum near the sand bed and the fitted $w_{\text {down }}$ $=6.0 \times 10^{-4} \mathrm{~cm} \mathrm{~s}^{-1}\left(=0.5 \mathrm{~m} \mathrm{~d}^{-1}\right)$. On 1 June, nauplii and copepodites were swimming upwards above the sand bed and the fitted $w_{\text {up }}=1.8 \times 10^{-3} \mathrm{~cm} \mathrm{~s}^{-1}\left(=1.5 \mathrm{~m} \mathrm{~d}^{-1}\right)$. Above the mussel bed, simulated vertical profiles were fitted against observed profiles by using the same $D$ and $w$ as for the sand bed and the fitted $w_{\max }=1.5$ to 2 and $5 \mathrm{~cm} \mathrm{~s}^{-1}$ for nauplii and copepodites, respectively.

The grazing impact on copepods and nauplii decreased with faster escape jumps on both days (Fig. 11b). On 28 May, at $w_{\max }$ and $w=0 \mathrm{~cm} \mathrm{~s}^{-1}$, the grazing impact was $5.6 \mathrm{~d}^{-1}$ for nauplii and $1.9 \mathrm{~d}^{-1}$ for copepodites (Table 2). Simulations with $w_{\text {down }}=6.0 \times$ $10^{-4} \mathrm{~cm} \mathrm{~s}^{-1}$ did not increase the grazing impact significantly (paired $t$-test, df $=8, \mathrm{p}>0.05$ ). The grazing impact on 1 June was 2 orders of magnitude lower than on 28 May $\left(w=0 \mathrm{~m} \mathrm{~s}^{-1}\right)$ and $w_{\text {up }}=1.8 \times$ $10^{-3} \mathrm{~cm} \mathrm{~s}^{-1}$ decreased the grazing impact by a further $39 \%$ on 1 June for $w_{\max }$ of 0 to $5 \mathrm{~cm} \mathrm{~s}^{-1}$ (paired $t$-test, $\mathrm{df}=5, \mathrm{p}<0.05)$

\section{Bivalve larvae}

Bivalve larvae swim upwards in helices with high directionality (Jonsson et al. 1991), due to negative geotaxis (Bayne 1964), interrupted by occasional sinking (Jonsson et al. 1991). Their swimming behaviour therefore consisted of a random component $D=$ $0.013 \mathrm{~cm}^{2} \mathrm{~s}^{-1}\left(u=0.091 \mathrm{~cm} \mathrm{~s}^{-1}\right.$ (Jonsson et al. 1991), $\gamma$ $=4 \mathrm{~s}$ ) and a component of directed swimming fitted as $W_{\text {up }}=1.2 \times 10^{-3} \mathrm{~cm} \mathrm{~s}^{-1}\left(=1 \mathrm{~m} \mathrm{~d}^{-1}\right)$ and $1.8 \times 10^{-3} \mathrm{~cm}$ $\mathrm{s}^{-1}\left(=1.5 \mathrm{~m} \mathrm{~d}^{-1}\right)$ on 28 May and 1 June, respectively, above the sand bed. There are no indications of escape responses for bivalve larvae (André et al. 1993). Using the fitted $w$ from the sand bed, the average $( \pm \mathrm{SD})$ simulated grazing impact was $8.2 \pm 0.6$ and $0.16 \pm 0.01 \mathrm{~d}^{-1}$ on 28 May and 1 June, respectively (Table 2).

\section{Seasonal perspective}

To evaluate the importance of heterotrophic organism to the consumption of mussels on a seasonal scale, the model simulations were combined with plankton data from the local monitoring programme (Limfjordsovervågningen 2002). Phytoplankton dominates the plankton biomass in early spring, whereafter the pelagic food web becomes more heterotrophic during summer and autumn in the Limfjord (Fig. 12a). The range in mussel consumption was evaluated by considering the 2 days modelled. For the low near-bed turbulence scenario (1 June), the average $( \pm \mathrm{SD})$ heterotro- 

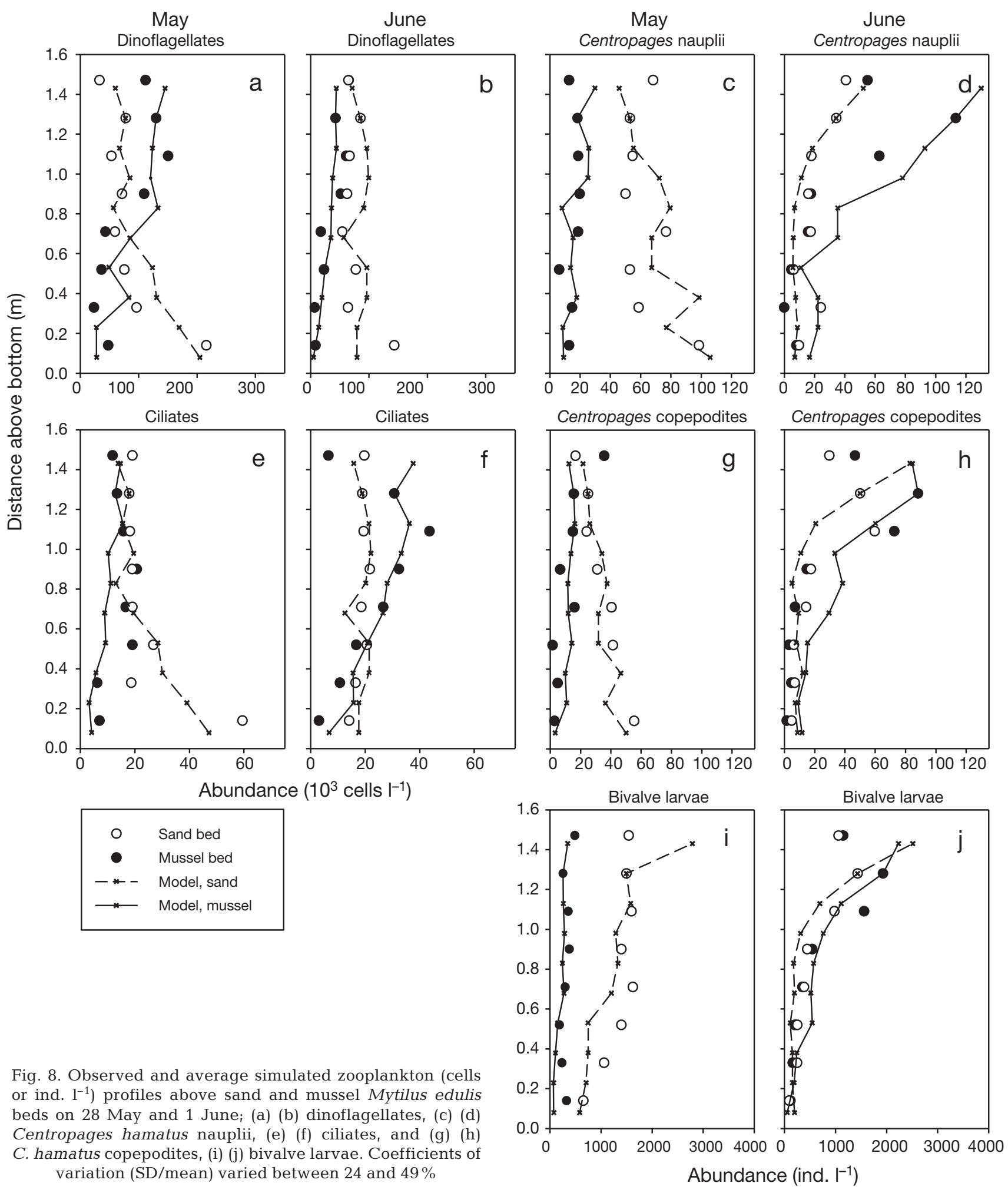

Fig. 8. Observed and average simulated zooplankton (cells or ind. $\mathrm{l}^{-1}$ ) profiles above sand and mussel Mytilus edulis beds on 28 May and 1 June; (a) (b) dinoflagellates, (c) (d) Centropages hamatus nauplii, (e) (f) ciliates, and (g) (h) C. hamatus copepodites, (i) (j) bivalve larvae. Coefficients of variation (SD/mean) varied between 24 and $49 \%$

phic contribution to mussel consumption was $17 \pm 3 \%$ during summer and autumn, while it was considerably lower during the spring bloom (Fig. 12c). For the high near-bed turbulence scenario (28 May), the higher grazing impact on bacteria, copepods and other zooplankton gave a heterotrophic contribution of $34 \pm 5 \%$ to mussel consumption during summer and autumn (Fig. 12b). 


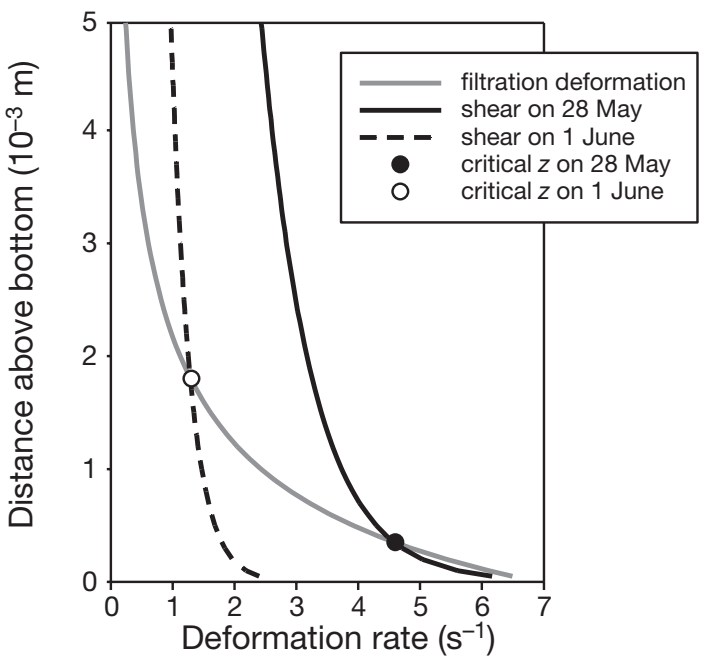

Fig. 9. Deformation rates generated by mussel Mytilus edulis filtration (Eq. 7) and micro-scale shear (Eq. 3) on 28 May and 1 June $<5.0 \times 10^{-3} \mathrm{~m}$ above mussel bed. Critical detection depths $(z)$ are shown

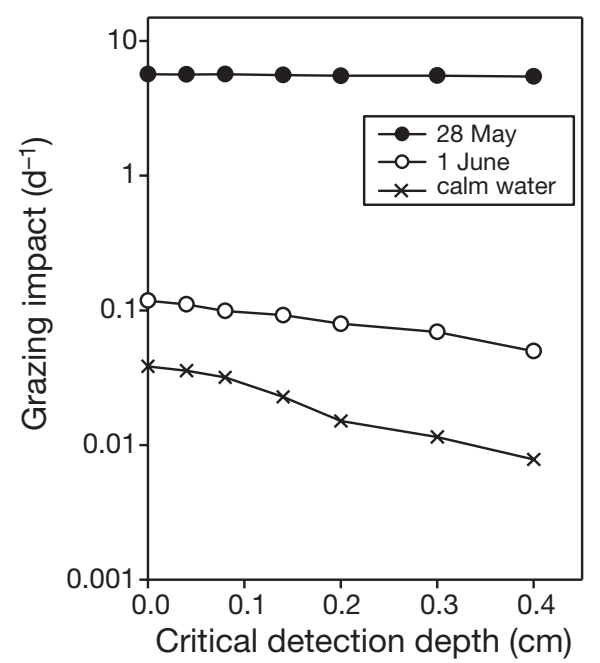

Fig. 10. Average simulated grazing impact $\left(\mathrm{d}^{-1}\right)$ on nauplii with biological diffusion $D=0.4 \times 10^{-2} \mathrm{~cm}^{2} \mathrm{~s}^{-1}$ and maximum escape velocitiy $w_{\max }$ of $2 \mathrm{~cm} \mathrm{~s}^{-1}$ as a function of increasing critical detection depth for $K$ on 28 May (high turbulence), 1 June (low turbulence), and in calm water $(K=0)$. Coefficients of variation were less than $2 \%$ on 28 May, $15 \%$ on 1 June and $40 \%$ in calm water

\section{DISCUSSION}

\section{Turbulent mixing}

Since external flushing and advection are limited in the Limfjord (Wiles et al. 2006), mussels cannot concentrate on relatively small, high-density beds as in tidal areas. Instead, they are spread over the system at relatively low local biomass but with a high standing stock on the system scale (Herman 2006). The biomass is lim- ited by vertical turbulent mixing that is responsible for the observed large variation in water column structure and in the transport of food to benthic mussels (Dolmer 2000a, Wiles et al. 2006). During the study period, turbulence levels were generally below the noise level of the accustic Doppler current profiler (ADCP) measurement system (Wiles et al. 2006). Turbulence was also measured by a Nortec 'Vector' acoustic Doppler velocimeter (ADV) employed 0.03 or $1.90 \mathrm{~m}$ above the beds under different weather conditions, confirming that maximum Reynolds stress $\sim 0.002 \mathrm{~Pa}$ (Wiles et al. 2006) was much lower than in (for example) shallow tidal areas ( 1 Pa) (Tweddle et al. 2005). Hence, the 2 levels of turbulence applied in the present study (Fig. 4) must be considered to be in the lower end of the turbulence spectrum in shallow waters, but typical for microtidal and regularly stratified areas such as most Danish estuaries (Rasmussen \& Josefson 2002).

Benthic mussels themselves can also influence the benthic boundary layer structure (van Duren et al. 2006). Mussels increase the roughness length of the bed with their shells and elevated siphons, thereby increasing turbulent transport (Butman et al. 1994, O'Riordan et al. 1995). The dynamics of exhalent jets are more complicated to resolve since they can either increase mixing (biomixing) in the logarithmic boundary layer (O'Riordan et al. 1995, Larsen \& Riisgaard 1997) or increase refiltration, depending on bivalve density, siphon height, filtration velocity and friction velocity (O'Riordan et al. 1995, Jonsson et al. 2005). A recent study showed that the exhalent jets above a $2 \mathrm{~m}$-long, dense bed of Mytilus edulis increased friction velocity by $56 \%$ at low flow speeds of $\sim 0.04 \mathrm{~m} \mathrm{~s}^{-1}$ and hence increased turbulent mixing (Lassen et al. 2006). Increased turbulent mixing above the mussel bed due to roughness and biomixing was included in the applied physical water column model by increasing the roughness length by a factor of 10 in comparison with the sand bed.

\section{Grazing impact on zooplankton}

Previous laboratory studies or analyses of stomach contents have shown that mussels graze on different zooplankton organisms (Lehane \& Davenport 2002, Green et al. 2003). The present study is the first attempt to model in situ grazing effects on the zooplankton community based on field observations of their vertical distributions. However, these profiles are not similar between days due to variation in water column stratification, turbulent mixing, advection, local plankton production and mussel population filtration rates (Møhlenberg 1995, Dolmer 2000b). Vertical profiles of phytoplankton and different zooplank- 


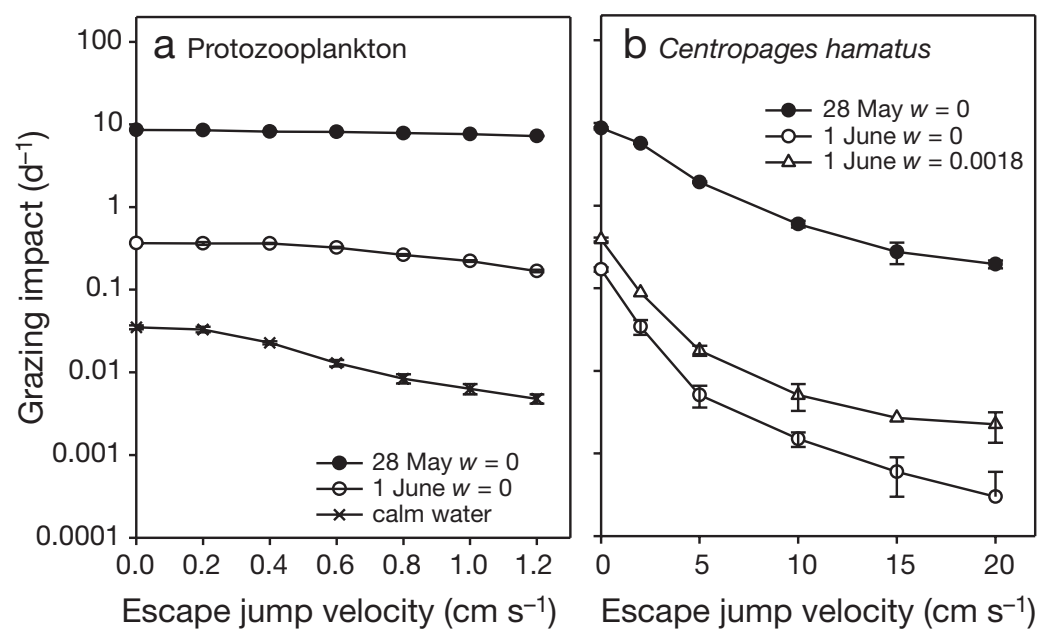

Fig. 11. Average $( \pm \mathrm{SE})$ simulated grazing impact versus maximum escape velocity for (a) protozooplankton ( $w=0 \mathrm{~cm} \mathrm{~s}^{-1}$ ) on 28 May (high turbulence), 1 June (low turbulence) and in calm water, and (b) Centropages hamatus nauplii and copepodites on 28 May and 1 June at $w=0 \mathrm{~cm} \mathrm{~s}^{-1}$ and $w_{\text {up }}=1.8 \times 10^{-3} \mathrm{~cm} \mathrm{~s}^{-1}$

ton organisms may differ from day to day since phytoplankton and zooplankton have different motility patterns and strengths. Additionally, some zooplankton can reduce the grazing impact by making escape jumps away from the predator (Broglio et al. 2001, Jakobsen 2002, Titelman \& Kiørboe 2003).

Simulated grazing impacts on protozooplankton were similar to those on chl a on both days (Table 2) indicating that protozooplankton are not successful in escaping mussel predation except during calm water conditions (Fig. 11). This is in agreement with a previous laboratory study (Kreeger \& Newell 1996) and the present field observations, where there were statistically significant different distributions of protozooplankton above the sand bed and mussel bed on both days. Calculated
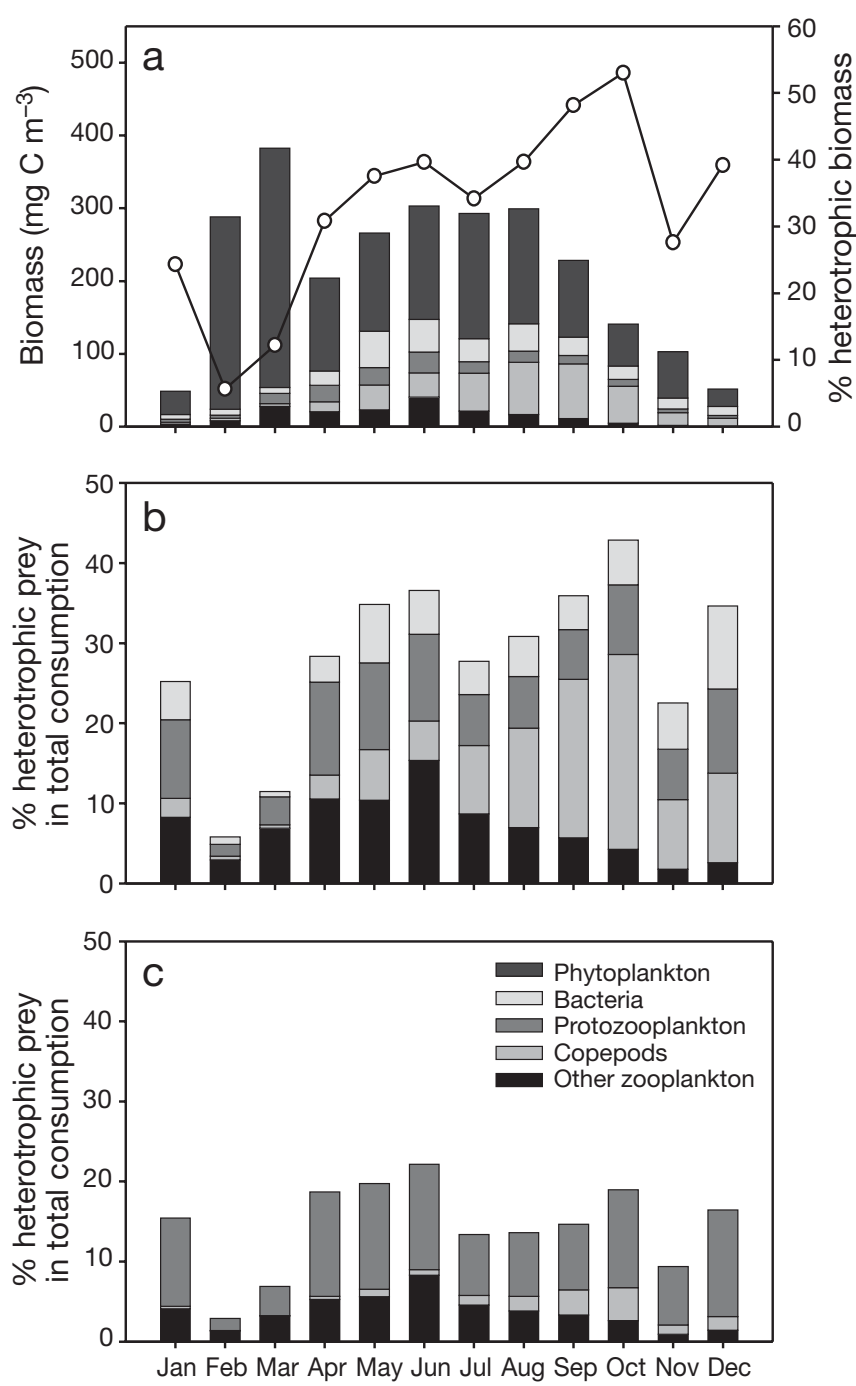

maximum specific growth rates and simulated grazing rates were in the same order of magnitude on 1 June (Table 2), and this may explain why the decrease in abundance was less pronounced then than on 28 May (Fig. 8a,b,e,f). The applied maximum escape velocities were within the range of previously reported values of up to $1.2 \mathrm{~cm} \mathrm{~s}^{-1}$ for ciliates and $0.7 \mathrm{~cm} \mathrm{~s}^{-1}$ for dinoflagellates (Table 3). For nauplii of Centropages hamatus, the model-fitted $w_{\max }$ corresponded to the escape jump velocities of $2 \mathrm{~cm} \mathrm{~s}^{-1}$ observed for C. typicus nauplii of similar size (Titelman \& Kiørboe 2003). Copepodites of C. hamatus were fitted to jump at a $W_{\max }$ of $5 \mathrm{~cm} \mathrm{~s}^{-1}$ that was within the observed range for different copepod species (Table 3). For C. hamatus nauplii and copepodites, increasing escape jumps reduced the simulated grazing impact considerably on both days (Fig. 11b). However, there was still considerable grazing impact on 28 May under the high turbulence conditions, causing decreasing abundance towards the mussel bed (Fig. 8c,g). In contrast, the simulated grazing impact on 1 June was negligible $\left(<0.02 \mathrm{~d}^{-1}\right)$ in agreement with observations (Fig. 8d,h). The escape success of copepod nauplii exposed to mussels in grazing experiments in calm water was up to $83 \%$ and

Fig. 12. Seasonal patterns of (a) average phytoplankton and zooplankton biomass $\left(\mathrm{mg} \mathrm{C} \mathrm{m}^{-3}\right)$ at Løgstør Bredning in Limfjord, Denmark 1985 to 2002 (combined data) and percentage heterotrophic contribution (line plot), and (b) percentage contribution of different zooplankton organisms to total consumption by mussels estimated from their biomass and grazing impact (Table 2) assuming high near-bed turbulence and consumption of bacteria (28 May) and (c) low near-bed turbulence without consumption of bacteria (1 June) 
Table 3. Critical deformation rates for detection of predators and escape-jump velocities $\left(w_{\max }\right)$ for different zooplankton groups reported in the literature

\begin{tabular}{|llll|}
\hline Group & $\begin{array}{c}\text { Critical deformation } \\
\text { rate }\left(\mathrm{s}^{1}\right)\end{array}$ & $\begin{array}{c}W_{\max } \\
\left(\mathrm{cm} \mathrm{s}^{-1}\right)\end{array}$ & Source \\
\hline Flagellates & $6.9-14.5$ & $0.4-0.7$ & Jakobsen (2002) \\
Ciliates & $1.8-3.0$ & $0.2-1.2$ & Jakobsen (2001), Broglio et al. (2001) \\
$\begin{array}{l}\text { Copepod nauplii } \\
\text { Copepodites }\end{array}$ & $0.5-4.2$ & $0.7-4.2$ & Titelman \& Kiørboe (2003), Green et al. (2003) \\
& $0.2-8.2$ & $1.5-12.8$ & Saiz \& Alcaraz (1992), Viitasalo et al. (1998), Kiørboe et al. (1999) \\
\hline
\end{tabular}

depended on copepod species and the flow field generated by mussel filtration (Green et al. 2003). Thus, nauplii and copepodites are able to perform successful escape jumps and overcome mussel filtration under conditions of low turbulent mixing.

Bivalves have been observed to feed on their own larvae (Lehane \& Davenport 2002), which do not seem to exhibit escape reactions (André et al. 1993). In contrast, meroplankton such as zoea larvae of Portunus spp. and metatrocophore larvae of Polydora ciliata showed clear escape reactions by turning and swimming away from the zone of suction (Singarajah 1975). Upward swimming by bivalve larvae due to negative geotaxis will, nevertheless, decrease their encounter with mussels, compared with purely diffusive behaviour. The modelfitted, upward swimming velocity resulted (together with a higher turbulence level) in a much higher grazing impact by mussels on 28 May than on 1 June. High turbulent shear $>2 \mathrm{~s}^{-1}$ has been shown to prevent bivalve larvae of Cerastoderma edule from leaving the near-bottom region $\left(<5 \times 10^{-4} \mathrm{~m}\right)$ due to interference with their swimming behaviour (Jonsson et al. 1991). This critical threshold corresponds to the shear above the mussel bed on 28 May ( $<0.007$ m, Fig. 9) in the present study; the shear never became that high on 1 June. Additionally, it has been observed that mussel larvae tumbled along the bottom in a high flow regime (Pernet et al. 2003). The confinement to the near-bottom drift will increase the risk of predation, and adult benthic suspension feeders can reduce the settlement of bivalve larvae by up to 20-40\% (André \& Rosenberg 1991). The confinement to the bottom layer in shallow turbulent waters can be beneficial for settling because the larvae can search for favourable habitats, provided that the density of adult benthic suspension feeders is low (André \& Rosenberg 1991).

\section{Mussel bed consumption}

The applied settling velocities of chl a were similar to those measured for organic particular matter during the study period $\left(0.4 \mathrm{~m} \mathrm{~d}^{-1}\right)$ (Herman 2006). Clearance rates of blue mussels have previously been estimated in the area from the density of mussels with open valves, gap size and pumping rates at different flow velocities when the water column was fully mixed (Dolmer 2000b). Dolmer (2006) found that during low flow velocities of $\sim 0.02 \mathrm{~m} \mathrm{~s}^{-1}$ at $1 \mathrm{~m}$ depth, up to $69 \%$ of the mussels had closed valves and filtration rate was 27 to $45 \%$ of their population clearance capacity of $23 \mathrm{~m}^{3}$ $\mathrm{m}^{-2} \mathrm{~d}^{-1}$. During higher flow speeds of $\sim 0.06 \mathrm{~m} \mathrm{~s}^{-1}$, fewer mussels had closed valves and the actual clearance rates were close to maximum. In the present study, clearance rates were 13.4 and $0.6 \mathrm{~m}^{3} \mathrm{~m}^{-2} \mathrm{~d}^{-1}$ on 28 May and 1 June, respectively, estimated from the grazing rate multiplied by water column depth $H=$ $1.5 \mathrm{~m}$. This corresponds to 14 and $1 \%$, respectively, of their clearance capacity of $94 \mathrm{~m}^{3} \mathrm{~m}^{-2} \mathrm{~d}^{-1}$ (Nielsen \& Maar 2007, this volume). These low ratios were probably due to low turbulent mixing under the present stratified conditions and the higher population clearance capacity compared to the study by Dolmer (2000b). During full mixing, the mussels will have access to the whole water column $(H=6 \mathrm{~m})$ and turbulence will increase, bringing new food into their vicinity. Episodic wind or wave-generated mixing of the water column occurs on the scale of days during summer (Wiles et al. 2006) and is thus crucial for mussel survival. In situ clearance rates of zebra mussels were also found to be $40 \%$ lower than those in the laboratory, due to reduced vertical mixing during stratification in Lake Erie (Ackerman et al. 2001).

In the Limfjord, the commercially exploited wild population of blue mussels covers $46 \%$ of the total area (Kristensen \& Hoffmann 2004). Hence, mussels are important in this area both economically and ecologically. In the present study, we also addressed zooplankton as a potential food source for mussel populations. The heterotrophic contribution to total consumption by mussels was estimated for an average seasonal cycle of the pelagic food web at Løgstør Bredning in the Limfjord (Fig. 12). During the spring bloom, consumption was dominated by phytoplankton (>88\%). However, in summer and autumn, heterotrophic prey was more prominent and contributed 34 and $17 \%$ of mussel consumption during high and low turbulent conditions, respectively. Although the assimilation efficiency of heterotrophs is lower than for phytoplankton (Kreeger \& Newell 1996, Wong \& Twining 2003), zooplankton 
are an important component of the natural diet of mussels, especially during periods with limited phytoplankton biomass, and should be taken into account in future investigations of mussel nutrition.

\section{Zooplankton community structure}

Nielsen \& Maar (2007, this volume) reported a significant difference in biomass and composition of the pelagic food web above a mussel bed and a bare sandy bottom. The present modelling corroborated the observations by documenting that high near-bed turbulence reduced the escape success even of large zooplankton and, hence, considerably increased the grazing impact by blue mussels relative to calm water situations (Fig. 11). At low turbulence, larger zooplankton escaped capture, and the grazing impact was not sufficient to reduce their abundance significantly. In conclusion, large zooplankton have the ability to grow and reproduce during periods of low turbulence without a strong benthic top-down control, which can be crucial to their overall growth and survival in shallow waters with dense mussel populations. This gives rise to a diverse zooplankton community that can compete with mussels for phytoplankton. During relatively high turbulence conditions, copepod abundance can be greatly reduced by mussels and thereby affect higher trophic levels such as fishes. Thus, we suggest that an on-off effect of mussel filtration on zooplankton, depending on the near-bed turbulence levels, controls the zooplankton community. Total mixing of the water column will increase the vertical transport of chl $a$ and zooplankton towards the mussels and the grazing impact by mussels can thereby affect the whole pelagic food web.

Acknowledgements. This study was supported by a Managing Benthic Ecosystems (MaBenE) Grant (EKV3-2001-00144) and Grant No.2104-05-0028 from the Danish Research Agency. We acknowledge J. Simpson, P. Wiles and C. Haese for providing ADCP measurements of flow velocities, T. Ysebaert for providing blue mussel data and I. G. Teixeira and B. G. Crespo for providing phytoplankton data. B. Søborg, J. Damgård Nielsen, J. N. Larsen and V. D. Hansen are thanked for technical assistance during the field study. P. J. M. Herman, E. F. Møller and 3 anonymous referees are thanked for suggestions of improvements on an earlier version of the present manuscript.

\section{LITERATURE CITED}

Ackerman JD, Loewen MR, Hamblin PF (2001) Benthicpelagic coupling over a zebra mussel reef in western Lake Erie. Limnol Oceanogr 46:892-904

André C, Rosenberg R (1991) Adult-larvae interactions in the suspension-feeding bivalves Cerastoderma edule and Mya arenaria. Mar Ecol Prog Ser 71:227-234
André C, Jonsson PR, Lindegarth M (1993) Predation on settling larvae by benthic suspension feeders: the role of hydrodynamics and larval behaviour. Mar Ecol Prog Ser 97: 183-192

Batchelor GK (2000) An introduction to fluid dynamics. Cambridge University Press, Cambridge

Bayne BL (1964) Responses of the larvae of mussels Mytilus edulis L. to light and gravity. Oikos 15:162-174

Berg HC (1983) Random walks in biology. Princeton University Press, Princeton

Broglio E, Johansson M, Jonsson PR (2001) Trophic interaction between copepods and ciliates: effects of prey swimming behavior on predation risk. Mar Ecol Prog Ser 220:179-186

Burchard H, Bolding K (2001) Comparative analysis of four second-moment turbulence closure models for the oceanic mixed layer. J Phys Oceanogr 31:1943-1968

Butman CA, Frechette M, Geyer WR, Starczak VR (1994) Flume experiments on food supply to the blue mussel Mytilus edulis L. as a function of boundary-layer flow. Limnol Oceanogr 39:1755-1768

Canuto VM, Howard A, ChengY, Dubovikov MS (2001) Ocean turbulence. Part I. One-point closure model. Momentum and heat vertical diffusivities. J Phys Oceanogr 31: $1413-1426$

Christiansen T, Christensen TJ, Markager S, Petersen JK (2006) Limfjorden i 100 år. Klima, hydrografi, næringsstoftilførsel, bundfauna og fisk i Limfjorden fra 1897 til 2003. Faglig Rapp fra DMU, No. 578, Miljøministeriet, Copenhagen

Cowden C, Young CM, Chia FS (1984) Diffential predation on marine invertebrate larvae by 2 benthic predators. Mar Ecol Prog Ser 14:145-149

Dolmer P (2000a) Algal concentration profiles above mussel beds. J Sea Res 43:113-119

Dolmer P (2000b) Feeding activity of mussels Mytilus edulis related to near-bed currents and phytoplankton biomass. J Sea Res 44:221-231

Frechette M, Butman CA, Geyer WR (1989) The importance of boundary layer flows in supplying phytoplankton to the benthic suspension feeder, Mytilus edulis L. Limnol Oceanogr 34:19-36

Green S, Visser AW, Titelman J, Kiørboe T (2003) Escape responses of copepod nauplii in the flow field of the blue mussel, Mytilus edulis. Mar Biol 142:727-733

Hansen PJ, Bjørnsen PK, Hansen BW (1997) Zooplankton grazing and growth: Scaling within the $2-2,000-\mu \mathrm{m}$ body size range. Limnol Oceanogr 42:687-704

Herman PMJ (2006) Managing benthic ecosystems in relation to physical forcing and environmental constraints. MaBenE EVK3-CT-2002-00071 Final Rep, Netherlands Institute of Ecology, Yerseke

Jakobsen HH (2001) Escape response of planktonic protists to fluid mechanical signals. Mar Ecol Prog Ser 214:67-78

Jakobsen HH (2002) Escape of protists in predator-generated feeding currents. Aquat Microb Ecol 26:271-281

Jonsson PR, André C, Lindegarth M (1991) Swimming behaviour of marine bivalve larvae in a flume boundary-layer flow: evidence for near-bottom confinement. Mar Ecol Prog Ser 79:67-76

Jonsson PR, Petersen JK, Karlsson Ö, Loo LO, Nilsson S (2005) Particle depletion above experimental bivalve beds: in situ measurements and numerical modelling of bivalve filtration in the boundary layer. Limnol Oceanogr 50: 1989-1998

Karp-Boss L, Boss E, Jumars PA (1996) Nutrient fluxes to planktonic osmotrophs in the presence of fluid motion. Oceanogr Mar Biol 34:71-107 
Kiørboe T, Møhlenberg F (1981) Particle selection in suspension-feeding bivalves. Mar Ecol Prog Ser 5:291-296

Kiørboe T, Visser AW (1999) Predator and prey perception in copepods due to hydromechanical signals. Mar Ecol Prog Ser 179:81-95

Kiørboe T, Saiz E, Visser AW (1999) Hydrodynamic signal perception in the copepod Acartia tonsa. Mar Ecol Prog Ser 179:97-111

Kreeger DA, Newell RIE (1996) Ingestion and assimilation of carbon from cellulolytic bacteria and heterotrophic flagellates by the mussles Geukensia demissa and Mytilus edulis (Bivalvia, Mollusca). Aquat Microb Ecol 11:205-214

Kristensen PS, Hoffmann E (2004) Bestanden af blåmuslinger i Limfjorden 1993-2003. DFU-Rapp No. 130-04, Danmarks Fiskeriundersøgelser, Charlottenlund

Larsen PS, Riisgaard HU (1997) Biomixing generated by benthic filter-feeders: a diffusion model for near-bottom phytoplankton depletion. J Sea Res 37:81-90

Lassen J, Kortegård M, Riisgaard HU, Friedrichs M, Graf G, Larsen PS (2006) Down-mixing of phytoplankton above filter-feeding mussels - interplay between water flow and biomixing. Mar Ecol Prog Ser 314:77-88

Lehane C, Davenport J (2002) Ingestion of mesozooplankton by three species of bivalve: Mytilus edulis, Cerastoderma edule and Aequipecten opercularis. J Mar Biol Assoc UK 82:615-619

Limfjordsovervågningen (2002) Plankton i Limfjorden 2002. Rapp til Limfjordovervågningen, Bio/consult AS, Åbyhøj

Møhlenberg F (1995) Regulating mechanisms of phytoplankton growth and biomass in a shallow estuary. Ophelia 42 : 239-256

Møhlenberg F, Riisgaard HU (1978) Efficiency of particle retention in 13 species of suspension feeding bivalves. Ophelia 17:239-246

Newell CR, Wildish DJ, MacDonald BA (2001) The effects of velocity and seston concentration on the exhalent siphon area, valve gape and filtration rate of the mussel Mytilus edulis. J Exp Mar Biol Ecol 262:91-111

Nielsen TG, Maar M (2007) Effects of a blue mussel Mytilus edulis bed on vertical distribution and composition of the pelagic food web. Mar Ecol Prog Ser 339:185-198

O'Riordan CA, Monismith SG, Koseff JR (1995) The effect of bivalve excurrent jet dynamics on mass transfer in a benthic boundary layer. Limnol Oceanogr 40(2):330-344

Pernet F, Tremblay R, Bourget E (2003) Settlement success, spatial pattern and behavior of mussel larvae Mytilus spp. in experimental 'down-welling' systems of varying velocity and turbulence. Mar Ecol Prog Ser 260:125-140

Editorial responsibility: Howard Browman (Associate Editorin-Chief), Storebø, Norway
Rasmussen B (1997) The near-surface horizontal buoyancy flux in a highly stratified region, Kattegat. Estuar Coast Shelf Sci 45:405-414

Rasmussen B, Josefson AB (2002) Consistent estimates for the residence time of micro-tidal estuaries. Estuar Coast Shelf Sci 54:65-73

Riisgaard HU, Seerup DF (2003) Filtration rates in the soft clam Mya arenaria: effects of temperature and body size. Sarsia 88:415-428

Saiz E, Alcaraz M (1992) Free-swimming behavior of Acartia clausii (Copepoda, Calanoida) under turbulent watermovement. Mar Ecol Prog Ser 80:229-236

Singarajah KV (1975) Escape reactions of zooplankton: effects of light and turbulence. J Mar Biol Assoc UK 55: $627-639$

Straile D (1997) Gross growth efficiencies of protozoan and metazoan zooplankton and their dependence on food concentration, predator-prey weight ratio, and taxonomic group. Limnol Oceanogr 42(6):1375-1385

Tiselius P, Jonsson PR (1990) Foraging behaviour of six calanoid copepods: observations and hydrodynamic analysis. Mar Ecol Prog Ser 66:23-33

Titelman J, Kiørboe T (2003) Predator avoidance by nauplii. Mar Ecol Prog Ser 247:137-149

Tweddle JF, Simpson JH, Janzen CD (2005) Physical controls of food supply to benthic filter feeders in the Menai Strait, UK. Mar Ecol Prog Ser 289:79-88

Umlauf L, Burchard H, Bolding K (2005) General ocean turbulence model. Source code documentation, Mar Sci Rep No. 63, Baltic Sea Research Institute, Warnemünde

van Duren LA, Herman PMJ, Sandee AJJ, Heip CHR (2006) Effects of mussel filtering activity on boundary layer structure. J Sea Res 55:3-14

Viitasalo M, Kiørboe T, Flinkman J, Pedersen LW, Visser AW (1998) Predation vulnerability of planktonic copepods: consequences of predator foraging strategies and prey sensory abilities. Mar Ecol Prog Ser 175: 129-142

Visser AW (1997) Using random walk models to simulate the vertical distribution of particles in a turbulent water column. Mar Ecol Prog Ser 158:275-281

Wiles PJ, van Duren LA, Häese C, Larsen J, Simpson JH (2006) Stratification and mixing in the Limfjorden in relation to mussel culture. J Mar Syst 60:129-143

Wong WH, Twining BS (2003) Assimilation of micro- and mesozooplankton by zebra mussels: a demonstration of the food web link between zooplankton and benthic suspension feeders. Limnol Oceanogr 48(1):308-312

Submitted: June 12, 2006; Accepted: October 16, 2006

Proofs received from author(s): April 26, 2007 